\title{
Motif Berprestasi dengan Komitmen Organisasi pada Guru Honorer di Sekolah Swasta
}

\author{
Norhasanah, Mulyani, dan Shanty Komalasari \\ Universitas Islam Negeri Antasari Banjarmasin
}

\begin{abstract}
The purpose of this study was to determine the relationship of achievement motives with organizational commitment to honorary teachers in private schools. The population in this study was honorary teachers of private schools, especially in the 4 schools, which amounted to 12 non-permanent employees. Sampling uses a quota sampling because the number of subjects is less than 30 subjects. The data in this study are quantitative data, data collection in this study is to use the questionnaire method in the form of scales, interviews, and documentation. The research data were analyzed using linear regression analysis. The results showed that there was no relationship between achievement motives and organizational commitment. The results of the calculation of correlation using the Spearman rank correlation coefficient test can be seen the value of Sig. (2-tailed) is 0,112. Meanwhile, the correlation coefficient value of 0,482 means that the strength of the correlation coefficient between the achievement motive variable and organizational commitment is sufficient. The percentage of effective contribution of achievement motivation influencing organizational commitment is only 1,82\% and $98,18 \%$ is influenced by variables or other factors not covered in this study.
\end{abstract}

Keywords: honorary teacher; organizational commitment; achievement motivation.

\begin{abstract}
Abstrak
Tujuan dari penelitian ini adalah untuk mengetahui hubungan motif berprestasi dengan komitmen organisasi pada guru honorer di sekolah swasta. Populasi dalam penelitian ini guru honorer sekolah swasta khususnya di 4 sekolah tersebut yaitu yang berjumlah 12 pegawai tidak tetap. Pengambilan sampel menggunakan kuota sampling karena jumlah subjek kurang dari 30 subjek. Data pada penelitian ini adalah data kuantitatif, pengumpulan data pada penelitian ini adalah menggunakan metode angket dalam bentuk skala, wawancara dan dokumentasi. Data penelitian dianalisis menggunakan analisis regresi linier Hasil penelitian menunjukkan bahwa tidak ada hubungan antara motif berprestasi dengan komitmen organisasi. Hasil perhitungan korelasi menggunakan uji koefisien korelasi spearman rank dapat diketahui nilai Sig. (2-tailed) adalah sebesar 0,112. Sementara itu nilai koefisien korelasi sebesar 0,482 artinya tingkat kekuatan hubungan koefisien korelasi antara variabel motif berprestasi dengan komitmen organisasi adalah cukup. Persentase sumbangan efektif motif berprestasi mempengaruhi komitmen organisasi hanya 1,82\% dan $98.18 \%$ dipengaruhi oleh variabel atau faktor lain yang tidak tercakup pada penelitian ini.
\end{abstract}

Kata Kunci: guru honorer; komitmen organisasi; motif berprestasi.

Pendidikan merupakan salah satu cara yang dapat membantu dalam membangun serta mengembangkan nilai-nilai yang ada di kehidupan. Nilai-nilai tersebut mencakup ilmu 
pengetahuan, budaya, serta agama. Pada umumnya ada sejumlah aspek yang sangat membantu dalam mencapai kesuksesan suatu lembaga pendidikan, meliputi pendidik, peserta didik, sarana dan prasarana, serta lingkungan pembelajaran dari sejumlah aspek yang ada di atas, guru memiliki kedudukan tertinggi dalam proses pembelajaran dan tidak melupakan aspek-aspek pendukung lainnya, guru merupakan seseorang yang sangat membantu dalam menggapai keberhasilan suatu pendidikan dan peran guru sangat signifikan bagi setiap keberhasilan proses pembelajaran (Widyaningrum, 2017).

Munculnya peraturan UU No. 20 tahun 2003 mengenai Tatanan Pendidikan Nasional, sebab itu menjadi alasan yang kuat untuk pemerintah mengikutsertakan seluruh penduduk dan pejabat negeri untuk mengelola institusi sekolah, baik dari strata sekolah dasar maupun pendidikan menengah. Keikutsertaan penduduk serta pihak pejabat negeri ini meliputi sejumlah unsur dari unsur pengawasan, unsur perencanaan, unsur pelaksanaan, dan unsur penilaian mengenai strategi institusi sekolah (UU No. 20, 2003, pasal 8), yang di dalamnya memuat kewajiban dalam membagikan bantuan sumber daya atas terselenggaranya lembaga pendidikan (UU No. 20, 2003, pasal 9). Hal ini menunjukkan bahwa para guru sangat penting untuk membantu menyukseskan pengajaran pendidikan (Cici , 2012).

Akan tetapi di dalam penelitian ditemukan bahwa kebanyakan guru honorer merasakan permasalahan yang sama. Seperti dalam penelitian Cici Asteriya Dewi mengenai pengaruh motivasi kerja terhadap kinerja guru honorer menyatakan bahwa "Guru tidak tetap yang mengajar di sekolah negeri maupun swasta hingga detik ini masih tidak mempunyai standar upah yang diterima dan jumlah imbalan yang sesuai dengan jam mengajar, serta tanggung jawab terhadap masa depan peserta didik, dan tingkat jabatan. Berbeda dengan guru yang berstatus PNS (Pegawai Negeri Sipil). Guru PNS mendapatkan gaji pokok, serta pihak pemerintah juga memberikan gaji pada bulan ke-13 untuk pegawai yang berstatus PNS dan juga pensiunan. Sebagaimana pada UU No. 43 Tahun 1999 atas perubahan UU No. 8 Tahun 1974 tentang pokok-pokok kepegawaian pada pasal 7, yang berbunyi "Seluruh pegawai negeri mempunyai hak untuk memperoleh gaji yang adil dan layak sesuai dengan beban pekerjaan dan tanggung jawabnya" (Astiti, 2015).

Masih banyak guru honorer non sertifikasi yang bertahan dalam pekerjaannya selama bertahun-tahun, meskipun mereka tahu bahwa kesempatan menjadi guru honorer sertifikasi itu sangat sulit dan belum pasti bisa diangkat menjadi guru honorer sertifikasi. Hal ini 
dikarenakan persyaratan untuk guru honorer sertifikasi itu ada batas umurnya sebagaimana di dalam UU No. 5 tahun 2014 tentang Aparatur Sipil Negara (ASN) yang mewajibkan masyarakat untuk mengikuti tahapan tes untuk menjadi abdi negara dan ditetapkan batas usia maksimal yang bisa diangkat menjadi CPNS adalah 35 tahun.

Luthan mengatakan bahwa "Ciri-ciri seseorang yang memiliki komitmen organisasi yaitu adanya keinginan yang kuat untuk tinggal dalam organisasi, kesediaan yang tinggi untuk menjadi bagian dari lembaga tersebut, memiliki kepercayaan yang tinggi, pengakuan terhadap nilai, dan tujuan dari lembaga tersebut. Robbins menjelaskan komitmen organisasi ialah "Seberapa besar seorang pegawai berpihak kepada organisasi serta memiliki tujuan yang sama terhadap organisasi dan adanya kemauan untuk mempertahankan keanggotaannya pada organisasi tersebut" (Yudha \& Hasib, 2014). Dalam Islam, komitmen adalah suatu ikrar yang mengharuskan setiap orang yang telah berjanji untuk melaksanakan janjinya. Dalam Islam ada istilah komitmen kinerja Islami. Komitmen kinerja Islami merupakan perasaan bersedia dan rela dengan cara memenuhi semua ketentuan yang telah ditetapkan oleh ajaran Islam. Tasmara juga berpendapat bahwa “Menjadi seorang muslim haruslah terlebih dahulu menampilkan dirinya sebagai manusia yang amanah, seseorang yang selalu mengabdi kepada Allah karena mereka menyadari bahwa dirinya di dunia ini hanya untuk beribadah" (Yudha \& Hasib, 2014). Seperti dalam firman Allah SWT dalam Q.S. adz-Dzariyaat/51: 56 sebagai berikut:

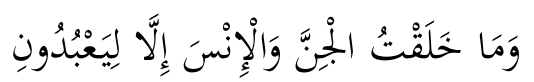

“Dan Aku tidak menciptakan jin dan manusia melainkan supaya mereka mengabdi kepada-Ku.

Di dalam penelitian Surahman menyatakan adanya hubungan yang signifikan antara komitmen organisasi dengan motivasi berprestasi, semakin tinggi komitmen organisasinya maka semakin tinggi pula motivasi berprestasi dan juga sebaliknya. Motif berprestasi menurut McClellan, motif berprestasi merupakan suatu dukungan dalam menyelesaikan sesuatu atau meningkatkan kinerja dalam suatu tugas dengan cara yang cepat dan efisien, lebih bagus dan lebih cepat dari pada orang lain, dan mencapai suatu standar unggul (standard of exellence) (Winasti \& Trainer, t.t.). Karyawan dengan motif berprestasi yang tinggi dapat menimbulkan kenyamanan dan kepuasan dalam bekerja. Tinggi rendahnya motif yang 
dimiliki karyawan dalam melakukan suatu pekerjaan memiliki dampak yang sangat besar terkait dengan sukses atau tidaknya usaha perusahaan dalam mencapai tujuannya.

\section{Metode}

Jenis penelitian yang digunakan yaitu penelitian lapangan (field research). Pendekatan yang dipakai pada penelitian ini menggunakan pendekatan kuantitatif. Subjek pada penelitian ini adalah guru honorer sekolah swasta khususnya 4 sekolah tersebut yang berjumlah 12 pegawai tidak tetap. Cara pengambilan sampel pada penelitian ini ialah dengan cara sampel jenuh. Sampel jenuh adalah cara pengambilan sampel menggunakan seluruh populasi yang akan dijadikan sebagai sampel. Disebabkan karena jumlah dari populasi yang ada kurang dari 30 subjek. Sehingga yang dijadikan sampel dalam penelitian ini ialah seluruh populasi yang berjumlah 12 guru honorer di sekolah swasta di empat lokasi tersebut. Pengumpulan data dalam penelitian ini menggunakan 2 skala psikologi yaitu skala komitmen organisasi dan skala motif berprestasi. Skala komitmen organisasi yang disusun berdasarkan dengan dimensi komitmen organisasi menurut Allen dan Mayer dan skala motif berprestasi disusun berdasarkan unsur-unsur motif berprestasi yang dikemukakan oleh McClelland (1985).

\section{Tabel 1}

Skala dan Aspek Penelitian

\begin{tabular}{cl}
\hline Skala & \multicolumn{1}{c}{ Aspek } \\
\hline Komitmen & 1. Komitmen affective \\
Organisasi & 2. Komitmen continuance \\
Motif & 3. Komitmen normative. \\
Berprestasi & 1. Kebutuhan berprestasi \\
& 2. Keinginan berprestasi \\
& 3. Antisipasi tujuan \\
& 4. Hambatan \\
& 5. Bantuan \\
& 6. Suasana \\
& 7. Perasaan \\
& 8. Tema berprestasi
\end{tabular}

Untuk hasil uji validitas pada skala motif berprestasi didapatkan item yang valid berjumlah 24 dan item yang tidak valid berjumlah 16. Peneliti menggunakan 18 item yang valid untuk digunakan sebagai skala motif berprestasi dan hasil uji validitas komitmen organisasi didapatkan hasil yaitu sebanyak 15 item yang valid dan 25 item yang tidak valid. 
Berdasarkan pada uji perhitungan reliabilitas yang menggunakan program SPSS 22.0 for windows didapatkan hasil untuk skala motif berprestasi $=0,940$ dan skala komitmen organisasi $=0,882$. Artinya data yang digunakan untuk skala motif berprestasi dan komitmen organisasi reliabel atau dapat dipercaya dan skala dapat dilanjutkan untuk penelitian.

Selain itu pada penelitian ini juga menggunakan dokumentasi, observasi, dan wawancara sebagai data pendukung. Analisis data pada penelitian ini yaitu analisis statistik dengan perhitungan statistik yang digunakan yaitu descriptive statistic. Serta menggunakan uji hipotesis analisis korelasi yaitu korelasi product moment. Korelasi merupakan arti dari statistik yang mengatakan bahwa adanya keterkaitan atau linier pada kedua variabel di dalam penelitian, yang ingin diteliti adalah hubungan di antara setiap variabel, variabel yang dimaksud yaitu variabel bebas (X) dan variabel terikat (Y). Uji pada 2 variabel ini menggunakan SPSS 22.0 for Windows untuk melakukan Test for Linearity dengan standar taraf signifikan 0,05 . Dua variabel bisa dinyatakan memiliki hubungan yang linier apabila nilai signifikansi kurang dari 0,05.

\section{H a s i 1}

Hasil dari deskriptif statistik untuk skala motif berprestasi dapat diketahui nilai dari mean pada skala motif berprestasi yaitu 50,83 dan standar deviasi 5,654. Artinya untuk tahap selanjutnya peneliti dapat membuat kriteria tingkatan sesuai dengan pedoman yang sudah ada. Untuk lebih jelasnya berikut ini adalah tabel kategorisasi:

Tabel 2

Tingkatan Frekuensi Subjek Skala Motif Berprestasi

\begin{tabular}{cccc}
\hline Kategori & Norma & Frekuensi & Rentang Nilai \\
\hline$X<45,176$ & Rendah & 1 & $8,3 \%$ \\
$45,176 \leq X \geq 56,484$ & Sedang & 9 & $75 \%$ \\
$56,484 \leq X$ & Tinggi & 2 & $16,7 \%$ \\
\hline
\end{tabular}

Berdasarkan pada tabel di atas dapat diketahui bahwa pada variabel motif berprestasi frekuensi subjek terbanyak ada pada tingkat sedang yaitu sebanyak 9 subjek dengan total persentase $75,0 \%$, pada tingkat tinggi sebanyak 2 subjek dengan total persentase $16,7 \%$, dan pada frekuensi rendah terdapat sebanyak 1 subjek dengan persentase 8,3\%. Artinya dari ketiga kategori tersebut, tingkat sedang memiliki frekuensi subjek terbesar dengan jumlah 9 
subjek dan total persentase sebesar 75,0\%. Berikut adalah tabel rekapitulasi data skor setiap subjek pada skala motif berprestasi:

Tabel 3

Rekapitulasi Data Motif Berprestasi

\begin{tabular}{ccc}
\hline Subjek & Skor & Tingkatan \\
\hline 1 & 59 & Tinggi \\
2 & 52 & Sedang \\
3 & 52 & Sedang \\
4 & 55 & Sedang \\
5 & 49 & Sedang \\
6 & 43 & Rendah \\
7 & 49 & Sedang \\
8 & 62 & Tinggi \\
9 & 51 & Sedang \\
10 & 45 & Sedang \\
11 & 46 & Sedang \\
12 & 47 & Sedang \\
\hline
\end{tabular}

Hasil dari deskriptif statistik untuk skala komitmen organisasi diperoleh nilai dari mean pada skala komitmen organisasi yaitu 43,67 dan standar deviasi 3,627. Artinya untuk tahap selanjutnya peneliti dapat membuat kriteria tingkatan sesuai dengan pedoman yang sudah ada. Untuk lebih jelasnya berikut ini adalah tabel kategorisasi:

Tabel 4

Tingkatan Frekuensi Subjek Komitmen Organisasi

\begin{tabular}{cccc}
\hline Kategori & Norma & Frekuensi & Rentang Nilai \\
\hline$X<40,043$ & Rendah & 1 & $8,3 \%$ \\
$40,043 \leq X \geq 47,297$ & Sedang & 9 & $75 \%$ \\
$47,297 \leq X$ & Tinggi & 2 & $16,7 \%$ \\
\hline
\end{tabular}

Berdasarkan pada tabel di atas dapat diketahui bahwa pada skala variabel komitmen organisasi frekuensi subjek terbanyak ada pada tingkat sedang yaitu sebanyak 9 subjek dengan total persentase $75,0 \%$. Kemudian pada tingkat tinggi sebanyak 2 subjek dengan total persentase $16,7 \%$, dan pada tingkat rendah sebanyak 1 subjek dengan persentase 8,3\%. Artinya dari ketiga kategori tersebut, tingkat sedang memiliki frekuensi subjek terbesar dengan jumlah 9 subjek dan total persentase sebesar 75,5\%. Berikut adalah tabel rekapitulasi data skor setiap subjek pada skala komitmen organisasi: 
Tabel 5

Rekapitulasi Data Motif Berprestasi

\begin{tabular}{ccc}
\hline Subjek & Skor & Tingkatan \\
\hline 1 & 51 & Tinggi \\
2 & 44 & Sedang \\
3 & 44 & Sedang \\
4 & 44 & Sedang \\
5 & 40 & Sedang \\
6 & 49 & Tinggi \\
7 & 40 & Sedang \\
8 & 46 & Sedang \\
9 & 43 & Sedang \\
10 & 43 & Sedang \\
11 & 39 & Rendah \\
12 & 41 & Sedang \\
\hline
\end{tabular}

Untuk mendapatkan hasil uji hipotesis dalam penelitian ini, peneliti menggunakan teknik analisis data dengan uji korelasi spearman rank untuk menguji hubungan dari dua variabel yang diteliti, yaitu hubungan motif berprestasi (variabel $\mathrm{X}$ ) dengan komitmen organisasi (variabel Y). Perhitungan uji spearman rank menggunakan program SPSS 22.0 for Windows untuk menguji hubungan antara motif berprestasi dengan komitmen organisasi. Adapun hasil untuk uji spearman rank dapat dilihat pada tabel berikut:

Tabel 6

Hasil Uji Korelasi Spearman Rank

\begin{tabular}{|c|c|c|c|c|}
\hline & & & Motif Berprestasi & Komitmen Organisasi \\
\hline \multirow[t]{6}{*}{$\begin{array}{l}\text { Spearman's } \\
\text { rho }\end{array}$} & $\begin{array}{l}\text { Motif } \\
\text { Berprestasi }\end{array}$ & $\begin{array}{l}\text { Correlation } \\
\text { Coefficient }\end{array}$ & 1,000 & ,482 \\
\hline & & Sig. (2-tailed) & $\cdot$ & 112 \\
\hline & & $N$ & 12 & 12 \\
\hline & $\begin{array}{l}\text { Komitmen } \\
\text { Organisasi }\end{array}$ & $\begin{array}{l}\text { Correlation } \\
\text { Coefficient }\end{array}$ & ,482 & 1,000 \\
\hline & & Sig. (2-tailed) & 112 & . \\
\hline & & $N$ & 12 & 12 \\
\hline
\end{tabular}

Berdasarkan pada tabel di atas diketahui nilai signifikansi atau sig. (2-tailed) sebesar 0,112 maka nilai sig. (2-tailed) lebih besar dari 0,05 (0,112>0,05). Artinya, tidak terdapat hubungan yang signifikan antara variabel motif berprestasi dengan komitmen organisasi. Karena jika nilai taraf signifikan lebih besar dari 0,05 maka tidak terdapat korelasi atau hubungan. Dan juga didapatkan hasil koefisien korelasi sebesar 0,482. Artinya, tingkat kekuatan hubungan koefisien korelasi antara variabel motif berprestasi dengan komitmen organisasi adalah cukup, karena 0,482 berada pada kekuatan hubungan koefisien korelasi 
cukup yaitu antara 0,26 sampai 0,50. Angka koefisien korelasi berdasarkan pada hasil uji korelasi spearman rank bernilai positif yaitu 0,482. Artinya, hubungan antara variabel motif berprestasi dengan komitmen organisasi tersebut bersifat searah, yaitu apabila motif berprestasi tinggi maka komitmen organisasi juga semakin tinggi.

Kemudian peneliti melakukan perhitungan uji determinasi dengan bantuan SPSS 22.0 for Windows untuk mencari tahu berapa besar persentase sumbangan efektif pengaruh variabel bebas (motif berprestasi) terhadap variabel terikat (komitmen organisasi). Adapun hasil dari uji analisis determinasi yaitu:

Tabel 7

Hasil Uji Determinasi

Model Summary

\begin{tabular}{ccccc}
\hline Model & $R$ & $R$ Square & Adjusted $R$ Square & Std. Error of the Estimate \\
\hline 1 &, $427^{\mathrm{a}}$ &, 182 &, 101 & 3,439 \\
\hline
\end{tabular}

a. Predictors: (Constant), Motif Bereprestasi

Berdasarkan pada tabel $4.11 \mathrm{di}$ atas dapat diketahui bahwa besarnya nilai korelasi atau hubungan (R) adalah 0,427. Dari output tersebut dapat diketahui koefisien determinasi ( $R$ Square) sebesar 0,182 atau $1.82 \%$. Artinya, persentase sumbangan efektif motif berprestasi mempengaruhi komitmen organisasi adalah sebesar 1.82\% dan 98.18\% sisanya dipengaruhi oleh faktor lain yang tidak masuk pada penelitian ini. Berikut adalah tabel rangkuman uji korelasi spearman rank:

Tabel 8

Rangkuman Hasil Penelitian

\begin{tabular}{ccccc}
\hline Sig. (2-tailed) & $R$ Square & Koefisien Korelasi & Keterangan & Kesimpulan \\
\hline 0,112 & 0,182 & 0,482 & Sig $\geq 0,05$ & Tidak Signifikan \\
\hline
\end{tabular}

Berdasarkan pada tabel 4.12 di atas dapat diketahui nilai Sig. (2-tailed) adalah sebesar 0,112. Sehingga berdasarkan pada hasil tersebut dapat dinyatakan bahwa hipotesis alternatif (Ha) ditolak yaitu tidak ada hubungan yang signifikan antara motif berprestasi dengan komitmen organisasi pada guru honorer di sekolah swasta. Sementara itu nilai koefisien korelasi sebesar 0,482 artinya tingkat kekuatan hubungan koefisien korelasi antara variabel motif berprestasi dengan komitmen organisasi adalah cukup. 


\section{Pembahasan}

Berdasarkan hasil pengujian hipotesis yang telah dilakukan, didapatkan bahwa variabel motif berprestasi tidak memiliki hubungan dengan komitmen organisasi pada guru honorer di sekolah swasta. Hasil ini tidak sejalan dengan penelitian Meiyanto dan Santhoso yang menyatakan bahwa tenaga kerja yang berkomitmen tinggi terhadap tugas menunjukkan hasil kerja yang baik dan memiliki motivasi kerja yang baik dan berkorelasi positif dengan meningkatnya motivasi kerja dan kepuasan kerja (Komalasari, 2007). Faktor yang mempengaruhi komitmen di antaranya adalah kebutuhan dan harapan yang di dalamnya mengandung faktor motivasi berprestasi, intelegensi, dan faktor persepsi (Lailiana \& Handayani, 2017). Penelitian Miyatun yang menyatakan bahwa ada hubungan antara motivasi berprestasi dengan komitmen organisasi dan juga yang dinyatakan oleh Carsten dan Spector yang menyebutkan jika semakin kuat perasaan komitmen organisasi pada individu maka dapat memberikan dampak pada setiap pegawai untuk memiliki keinginan selalu berada di dalam organisasi dan juga dapat meningkatkan prestasinya dalam bekerja (Dwi Darma, 2016).

Pada penelitian ini, peneliti mengajukan hipotesis dalam penelitian ini yaitu adanya hubungan antara motif berprestasi dengan komitmen organisasi pada guru honorer di sekolah swasta untuk menjawab rumusan masalah yang ketiga. Pada penelitian ini peneliti menggunakan SPSS 22.0 for Windows untuk membantu dalam melakukan perhitungan yang ada dalam penelitian ini. Berdasarkan hasil perhitungan korelasi menggunakan uji koefisien korelasi spearman rank dapat diketahui nilai Sig. (2-tailed) adalah sebesar 0,112. Sehingga berdasarkan pada hasil tersebut dapat dinyatakan bahwa hipotesis alternatif (Ha) ditolak, yaitu tidak ada hubungan yang signifikan antara motif berprestasi dengan komitmen organisasi pada guru honorer di sekolah swasta. Sementara itu nilai koefisien korelasi sebesar 0,482 artinya tingkat kekuatan hubungan koefisien korelasi antara variabel motif berprestasi dengan komitmen organisasi adalah cukup dan diketahui koefisiennya bernilai positif antara variabel motif berprestasi dengan komitmen organisasi dan diketahui hasilnya bersifat searah, yaitu apabila motif berprestasi tinggi maka komitmen organisasi juga semakin tinggi.

Motif adalah energi yang memberikan arah bagi pelaku. Suprihanto mengatakan bahwa motivasi merupakan salah satu masalah yang kompleks dalam organisasi, karena kebutuhan dan keinginan setiap anggota organisasi adalah unik secara biologis dan 
psikologis, dan berkembang atas dasar yang berbeda pula. Berbagai upaya untuk meningkatkan prestasi karyawan tentunya akan diupayakan oleh perusahaan, akan tetapi karena banyaknya faktor yang menentukan motif karyawan untuk berprestasi mengakibatkan upaya ini untuk tidak mudah dicapai (Komalasari, 2007). Terdapat dua faktor yang mendasari motivasi seseorang, pertama adalah faktor yang menimbulkan kepuasan kerja yang dinamakan faktor motivator yang merupakan faktor intrinsik, faktor kedua adalah faktor ekstrinsik. Faktor pertama merupakan faktor pendorong seseorang untuk berprestasi yang bersumber dalam diri seseorang tersebut (kondisi intrinsik), sedangkan faktor kedua merupakan faktor yang berkaitan dengan pemenuhan kebutuhan, seperti gaji yang merupakan tempat pemenuhan kebutuhan tingkat rendah yang dikualifikasikan ke dalam faktor ekstrinsik. Kondisi karyawan yang termotivasi secara intrinsik akan memiliki energi untuk segera menyelesaikan pekerjaan (Komalasari, 2007).

Adapun pengertian motif berprestasi menurut McClelland, motif berprestasi merupakan suatu dukungan dalam menyelesaikan sesuatu atau meningkatkan kinerja dalam suatu tugas dengan cara yang cepat dan efisien, lebih bagus dan lebih cepat dari pada orang lain, dan mencapai suatu standar unggul (standard of exellence) (Winasti \& Trainer, t.t.). Eysenck mengatakan bahwa seseorang yang memiliki motif berprestasi yang kuat memiliki ciri mempunyai ambisi yang kuat, suka bersaing (berkompetisi), selalu bekerja keras, dan tekun dalam mengubah status sosial (Komalasari, 2007). Akan tetapi hal ini berbanding terbalik dengan hasil penelitian setelah dilakukan wawancara kepada dua subjek penelitian diketahui bahwa subjek tidak memiliki ambisi yang kuat atau suka berkompetisi karena mereka merasa bahwa memiliki kesamaan status pekerjaan mereka dengan guru-guru lainnya. Hal ini di faktorkan karena lingkungan tempat mereka bekerja diketahui bahwa semua guru yang ada di sekolah tersebut berstatus honorer maka dari itu hal ini menurunkan motif berprestasinya. Menurut Wigfield dan Eccles dalam model skala kognitif menyebutkan motivasi berprestasi dipengaruhi oleh dunia sosial (lingkungan sosial), proses kognitif (persepsi), dan kepercayaan motivasi (nilai tugas dan harapan) (Yulita, 2003). Setelah mendapatkan hasil peneliti menanyakan ke responden. Peneliti memperdalam lagi dan menggali informasi apa yang menyebabkan motif berprestasi dengan komitmen organisasi tidak memiliki hubungan dengan menggunakan metode wawancara, berikut wawancara dengan 2 orang responden: 
Tabel 9

Hasil Wawancara

\begin{tabular}{c} 
Hesponden \\
\hline 1 \\
Saya masih ingin bertahan sebagai guru honorer karena banyak hal yang saya \\
dapat. Yaitu rasa nyaman, bertambahnya wawasan, dapat mengenal anak-anak, \\
orang tua murid, dan banyak mendapatkan pelajaran dari berbagai masalah yang \\
dialami anak-anak. Sebagai guru honorer ini jelas gajihnya tidak mecukupi, tapi \\
saya tetap ingin bertahan karena saya memang menyukai pekerjaan ini. Menjadi \\
guru honorer ini sebenarnya tidak ada jaminan untuk tetap dipertahankan, bisa \\
saja suatu saat diberhentikan, salah satu upaya saya untuk tetap bisa \\
dipertahankan dalam pekerjaan ini, ialah dengan bekerja sebaik-baiknya dan jika \\
diberi tugas langsung saya kerjakan tepat waktu, akan tetapi untuk terlihat lebih \\
unggul dari teman sekerja tidak ada dan kami selalu saling membantu jika ada \\
teman yang tidak mengerti dengan tugasnya. \\
Saya bekerja sebagai guru honorer selama 10 tahun, saya merasa nyaman bekerja \\
sebagai guru honorer meskipun dengan gaji yang sedikit, saya merasa nyaman \\
bekerja di sana karena lingkungannya serta teman-teman sekerja yang membuat \\
itu nyaman. Saya sudah tidak dapat lagi mendaftar menjadi PNS karena umur \\
saya sudah 45 tahun, tapi saya tetap bertahan karena sudah tidak ada pekerjaan \\
lain dan susah mencari pekerjaan lain dengan umur saya segitu. Ada ketakutan \\
yang saya rasakan, saya takut diberhentikan, agar saya tidak diberhentikan saya \\
selalu bekerja dengan sebaik-baiknya dalam menjalankan tugas-tugas di sekolah, \\
saya tidak pernah mengerjakan tugas untuk melebihi teman-teman lainnya \\
karena kami sama saja, sama-sama guru honorer dan semuanya guru honorer \\
serta ada juga yang lebih tua dari saya.
\end{tabular}

Jadi berdasarkan wawancara tersebut diketahui bahwa motif berprestasi dengan komitmen organisasi tidak berhubungan dikarenakan tidak adanya keinginan untuk melebihi atau lebih unggul dari teman sekerja. Hal ini didasari oleh perasaan setara sehingga tidak terdorong untuk lebih baik dari orang lain.

Pada penelitian ini juga, peneliti ingin mengetahui bagaimana tingkat motif berprestasi pada guru honorer sesuai dengan rumusan masalah yang pertama. Berdasarkan pada nilai dari mean pada skala motif berprestasi yaitu sebesar 50,83 dan nilai dari standar deviasinya sebesar 5,654. Dari hasil mean dan standar deviasi dapat diketahui frekuensi responden terbanyak ada pada kategori sedang yaitu sebanyak 9 subjek dengan total persentase $75,0 \%$. Kemudian pada tingkat tinggi sebanyak 2 subjek dengan total persentase $16,7 \%$, dan pada tingkat rendah sebanyak 1 subjek dengan persentase 8,3\%. Secara umum motif berprestasi pada guru honorer di sekolah swasta berada dalam kategori sedang. Motif berprestasi pada tingkatan sedang ini juga bisa dikatakan dalam keadaan baik. Hal ini mengacu pada tingkat persentase di atas dapat disimpulkan bahwa seluruh responden 
memberikan jawaban atas item pernyataan yang diajukan menunjukkan tingkat perilaku motif berprestasi atau mendekati tingkat yang diharapkan dalam pernyataan tersebut.

Menurut Atkinson motif merupakan suatu kebutuhan untuk mempertahankan kelangsungan hidup, kebutuhan sosial dan kebutuhan untuk memuaskan keingintahuan (Yulita, 2003). Abraham Maslow menyatakan bahwa manusia dimotivasi untuk memenuhi sejumlah kebutuhan yang melekat pada diri setiap manusia yang cenderung bersifat bawaan. Setiap manusia memiliki kebutuhan dasar yaitu kebutuhan primer individu, kebutuhan ini harus dipenuhi agar tetap hidup, misalnya kebutuhan sandang, papan dan pangan. Ketiga kebutuhan tersebut merupakan kebutuhan yang utama. Jika ketiga kebutuhan tersebut mengalami gangguan atau kekurangan maka kemungkinan kebutuhan-kebutuhan lainnya akan mengalami gangguan. Kebutuhan akan keamanan yang dimaksud merupakan keselamatan yang merujuk rasa aman dari setiap ancaman fisik untuk kehilangan, serta merasa terjamin, misalnya dengan melakukan asuransi untuk dirinya maupun usahanya yang bertujuan agar jika suatu saat terjadi hal yang tidak diinginkan maka sudah ada jaminan untuk dirinya. Kebutuhan sosial merupakan kebutuhan antar manusia yang dicerminkan dalam kebutuhan untuk menjadi bagian dari kelompok sosial seperti kebutuhan akan perasaan diterima oleh orang lain. Kebutuhan akan persahabatan dan bantuan itu diwujudkan dalam bentuk interaksi dengan rekan kerja untuk mendapatkan kepuasan dalam berinteraksi dengan orang lain. Kebutuhan akan penghargaan, pada kebutuhan ini seseorang mengharapkan pengakuan dari orang lain, kaitannya dengan pekerjaan hal itu berarti memiliki pekerjaan yang diakui sehingga, menyediakan sesuatu yang dapat dicapai, serta pengakuan umum dan penghormatan dari dunia luar. Kebutuhan pengakuan atau aktualisasi diri merupakan kebutuhan ditingkatkan paling atas atau berkaitan dengan keinginan untuk pemenuhan diri dari kebutuhan lain yang sudah terpuaskan. Motivasi berperan sebagai kekuatan mental individu. Seseorang yang melakukan sesuatu hal karena didasarkan pada kebutuhan individu tersebut. Bila satu tingkatan kebutuhan sudah terpenuhi, maka akan muncul tingkat kebutuhan yang lebih tinggi, tingkat kebutuhan ini tidak harus terpenuhi $100 \%$. Hal ini karena kebutuhan dengan tingkatan yang lebih rendah belum tercapai secara maksimal (Handayani, 2017).

McClelland (1987) mengatakan bahwa seseorang yang memiliki motif berprestasi yang tinggi maka seseorang tersebut pasti memiliki rasa tanggung jawab dan rasa percaya 
diri yang tinggi, lebih cekatan, lebih rajin dalam setiap mengerjakan suatu pekerjaan, serta memiliki keinginan yang kuat untuk menggapai sebuah kesuksesan dan memiliki keinginan untuk menyelesaikan setiap tugas dengan sebaik-baiknya. Maka sebab itu orang yang memiliki motif berprestasi yang tinggi akan mendapatkan hasil prestasi akademik yang hasilnya lebih baik daripada seseorang yang memiliki motif berprestasi rendah (Dwi Darma, 2016).

Pada penelitian ini motif berprestasi dalam kategori sedang, maka peneliti juga ingin mengetahui bagaimana tingkat komitmen organisasi pada guru honorer sesuai dengan rumusan masalah yang kedua. Pada nilai dari mean pada skala komitmen organisasi yaitu sebesar 43,67 dan standar deviasi sebesar 3,627. Dari hasil mean dan standar deviasi dapat diketahui frekuensi responden terbanyak ada pada kategori sedang yaitu sebanyak 9 subjek dengan total persentase $75,0 \%$. Kemudian pada tingkat tinggi sebanyak 2 subjek dengan total persentase $16,7 \%$, dan pada tingkat rendah sebanyak 1 subjek dengan persentase $8,3 \%$. Secara umum komitmen organisasi pada guru honorer di sekolah swasta berada dalam kategori sedang. Hal ini mengacu pada tingkat persentase di atas dapat disimpulkan bahwa seluruh responden memberikan jawaban atas item pernyataan yang diajukan menunjukkan tingkat perilaku komitmen organisasi atau mendekati tingkat yang diharapkan dalam pernyataan tersebut.

Komitmen organisasi yaitu perasaan yang dirasakan individu, individu tersebut merasa adanya keterkaitan secara perasaan psikologis dan fisik pegawai kepada organisasi di mana tempat ia bekerja. Keterkaitan secara psikologis yang dimaksud adalah perasaan yang didapat oleh pegawai berupa rasa senang dan bangga ketika bekerja di sebuah organisasi dan merasa senang ketika menjadi bagian dalam anggota sebuah organisasi. Ketertarikan itu terjadi dalam tiga sikap yaitu selalu mematuhi norma yang ada di organisasi, mematuhi nilainilai, dan peraturan di dalam organisasi (Wirawan, 2013).

Menurut Steer dan Porter bahwa terdapat beberapa penyebab yang mempengaruhi komitmen karyawan pada organisasi yaitu: faktor personal meliputi harapan kerja, kontrak psikologis, pilihan pekerjaan, dan karakteristik personal (kepribadian) seperti usia dan jenis kelamin sebab keseluruhan faktor ini akan membentuk komitmen awal, hal ini sesuai dengan usia pada guru honorer yang diteliti di mana semua guru honorer ini memiliki umur lebih dari 34 tahun, dengan memiliki umur 34 tahun lebih hal ini akan menjadi hambatan pada 
setiap guru untuk mencari pekerjaan lain maka hal ini akan dapat membantu dalam pembentukan komitmen. Faktor organisasi, mencakup pengalaman kerja, lingkungan pekerjaan, pengawasan, dan konsistensi tujuan organisasi semua ini dapat menghasilkan serta membangun sebuah rasa bertanggung jawab. Dan yang terakhir Non-organizational factors, yaitu meliputi tersedianya pekerjaan alternatif. Aspek-aspek ini bukan bersumber dari organisasi, melainkan karena tidak adanya pilihan pekerjaan lain yang dapat diambil. Jika mendapatkan pekerjaan yang lebih bagus dari pekerjaan yang dijalaninya maka pegawai tersebut akan meninggalkan perusahaan itu (Dwi Darma, 2016).

Selanjutnya peneliti melakukan penghitungan untuk melihat berapa besar sumbangan efektif motif berprestasi mempengaruhi komitmen organisasi pada guru honorer di sekolah swasta untuk menjawab rumusan masalah keempat. Melalui uji determinasi menggunakan SPSS 22.0 for Windows diperoleh hasil koefisien determinasi ( $R$ square) sebesar 0,182 sehingga dapat diartikan bahwa adanya pengaruh dari variabel bebas (motif berprestasi) terhadap variabel terikat (komitmen organisasi) yakni sebesar 1,82\% yang mana dapat diartikan bahwa sebanyak $98.18 \%$ dipengaruhi oleh variabel atau faktor lain yang tidak tercakup pada penelitian ini. Menurut Ayeni \& Phopoola (2007) menemukan hubungan yang kuat antara kepuasan kerja dengan komitmen organisasi. Menurut mereka kepuasan kerja sebagian terbesar ditentukan oleh seberapa baik organisasi memenuhi harapan para pegawai. Menurut Cole dan Heslin (2003) alasan mengapa kepuasan kerja akan mengarah kepada komitmen adalah kepuasan kerja akan mengarah ke kehidupan kerja yang baik dan pengurangan stres. Jika para pegawai puas tinggi dengan pekerjaan mereka, teman sekerja, upah, supervisi, dan memperoleh kepuasan kerja tinggi terhadap pekerjaannya, mereka lebih mungkin berkomitmen terhadap organisasinya dibandingkan jika mereka tidak puas terhadap pekerjaannya. Kepuasan kerja dan komitmen organisasi merupakan faktor penentu terhadap pindah kerja, kinerja, dan produktivitas (Wirawan, 2013). Komitmen organisasi berhubungan juga dengan motivasi, seperti yang ada pada penelitian yang dilakukan oleh Elit Prambara Yudha dan Fatin Fadhillah Hasib diperoleh hasil bahwa adanya korelasi positif yang signifikan $(r=0,767$ dan $p=0.000)$ antara motivasi dengan komitmen organisasi (Yudha \& Hasib, 2014). Kemudian dari hasil penelitian yang dilakukan oleh Karmelita Agni Ayu Pratiwi diperoleh hasil bahwa ada hubungan korelasi positif yang signifikan $(r=0,803$ dan $p=0.00)$ antara motivasi berprestasi dan iklim organisasi dengan komitmen organisasi. Dan penelitian 
Komalasari diperoleh hasil bahwa ada hubungan yang negatif yang signifikan $(r=-0,425$ dan $p=0,001)$ antara motif berprestasi dengan prokrastinasi kerja (Komalasari, 2007).

Jadi, berdasarkan hasil pemaparan di atas dapat disimpulkan bahwa tidak terdapat hubungan antara motif berprestasi dengan komitmen organisasi. Hal ini berdasarkan pada hasil perhitungan korelasi menggunakan uji koefisien korelasi spearman rank dapat diketahui nilai Sig. (2-tailed) adalah sebesar 0,112. Dapat diketahui nilai 0,112 lebih besar dari 0,05 (0,112 $>0,05)$. Artinya, tidak terdapat hubungan yang signifikan antara variabel motif berprestasi dengan komitmen organisasi. Sehingga berdasarkan pada hasil tersebut dapat dinyatakan bahwa hipotesis alternatif (Ha) ditolak yaitu tidak ada hubungan yang signifikan antara motif berprestasi dengan komitmen organisasi pada guru honorer di sekolah swasta. Sementara itu nilai koefisien korelasi sebesar 0,482. Artinya, tingkat kekuatan hubungan koefisien korelasi antara variabel motif berprestasi dengan komitmen organisasi adalah cukup, karena 0,482 berada pada kekuatan hubungan koefisien korelasi cukup yaitu antara 0,26 sampai 0,50. Angka koefisien korelasi berdasarkan pada hasil uji korelasi spearman rank bernilai positif yaitu 0,482 . Artinya, hubungan antara variabel motif berprestasi dengan komitmen organisasi tersebut bersifat searah, yaitu apabila motif berprestasi tinggi maka komitmen organisasi juga semakin tinggi.

\section{Kesimpulan}

Berdasarkan pada hasil penelitian hubungan motif berprestasi dengan komitmen organisasi pada guru honorer di sekolah swasta, maka dapat ditarik kesimpulan bahwa tingkat motif berprestasi dan komitmen organisasi pada guru honorer di sekolah swasta berada pada tingkat sedang yaitu sebanyak 9 subjek dengan total persentase $75,0 \%$. Hal ini mengacu pada tingkat persentase di atas dan dapat disimpulkan bahwa seluruh responden memberikan jawaban atas item pernyataan yang telah diajukan dan menunjukkan tingkat perilaku motif berprestasi dan komitmen organisasi atau mendekati tingkat yang diharapkan dalam pernyataan tersebut. Serta diketahui bahwa tidak ada hubungan antara motif berprestasi dengan komitmen organisasi pada guru honorer di sekolah swasta. Hal ini berdasarkan pada hasil perhitungan dapat diketahui bahwa nilai Sig. (2-tailed) adalah sebesar 0,112 . Sementara itu diketahui juga nilai koefisien korelasi sebesar 0,482 yang artinya tingkat kekuatan hubungan koefisien korelasi antara variabel motif berprestasi dengan komitmen 
organisasi adalah cukup dan dapat dikatakan bernilai positif yaitu 0,482. Artinya, hubungan antara variabel motif berprestasi dengan komitmen organisasi tersebut bersifat searah, yaitu apabila motif berprestasi tinggi maka komitmen organisasi juga semakin tinggi.

Persentase sumbangan efektif motif berprestasi mempengaruhi komitmen organisasi pada guru honorer di sekolah swasta. Melalui uji determinasi menggunakan SPSS 22.0 for Windows dan diketahui hasil dari perhitungan koefisien determinasi ( $R$ square) sebesar 0,182. Artinya persentase sumbangan efektif motif berprestasi mempengaruhi komitmen organisasi hanya $1,82 \%$ dan $98.18 \%$ dipengaruhi oleh variabel-variabel atau faktor-faktor lain yang tidak tercakup dengan penelitian ini.

Saran

Berdasarkan pada penelitian yang telah dilaksanakan oleh peneliti, maka peneliti menyadari bahwa masih banyak terdapat kekurangan di dalam penelitian ini. Sehingga peneliti ingin memberikan saran untuk peneliti-peneliti selanjutnya yang nantinya akan melakukan penelitian terkait dengan variabel motif berprestasi dan variabel komitmen organisasi. Adapun saran yang diberikan bagi peneliti selanjutnya yang ingin melakukan penelitian mengenai motif berprestasi atau komitmen organisasi, agar melakukan penelitian terhadap variabel lain seperti lingkungan kerja dan kepuasan kerja yang belum diteliti atau dibahas dalam penelitian ini dan diharapkan pada perpustakaan Fakultas Ushuluddin dan Humaniora dan perpustakaan Universitas Islam Negeri Antasari Banjarmasin agar dapat memperbanyak buku-buku terkait motif berprestasi dan komitmen organisasi khususnya. Serta buku mengenai Psikologi Industri dan Organisasi pada umumnya. Untuk lembaga terkait untuk dapat memberikan penghargaan kepada guru-guru sehingga dapat menumbuhkan rasa keinginan yang kuat untuk berprestasi dan mencapai target yang telah ditentukan oleh sebuah organisasi.

\section{Daftar Pustaka}

Dwi Darma, S. (2016). Pengaruh Motivasi, Pelatihan, Dan Komitmen Organisasi Terhadap Kinerja Karyawan Melalui Kepuasan Kerja Sebagai Variabel Intervening Pada Divisi Sdi Pt. Bank Bri Syariah Kantor Pusat [Skripsi].

Handayani, D. P. (2017). Program Studi Manajemen Fakultas Ekonomi Dan Bisnis Universitas Pasundan Bandung. 2.

Honorer, G. (T.T.-A). Pengaruh Motivasi Kerja Terhadap Kinerja. 113. 
Komalasari, S. (2007). Program Studipsikologi Fakultas Psikologi Dan Ilmif Sosial Budaya Umversitas Islam Indonesia Yogyakarta. 135.

Lailiana, N. A., \& Handayani, A. (2017). Motivasi Berprestasi Ditinjau Dari Komitmen Terhadap Tugas Pada Mahasiswa. 8.

Mohammad Ula. (2016). Pengaruh Komitmen Organisasi Dan Iklim Organisasi Terhadap Retensi Karyawan Pada Pt. Selok Jaya Di Kecamatan Juwana, [Skripsi].

Widyaningrum, R. (2017). Penanaman Sikap Peduli Lingkungan Dan Sikap Ilmiah Siswa Sekolah Dasar Melalui Sosialisasi Program Sekolah Peduli Dan Berbudaya Lingkungan. 14.

Winasti, S. A., \& Trainer, S. (2016). Hubungan Antara Iklim Organisasi Dan Motif Berprestasi Karyawan Kantor Notaris \& Ppat. 9.

Wirawan. (2013). Kepemimpinan: Teori, Psikologi, Perilaku Organisasi, Aplikasi Dan Penelitian,. Pt. Raja Grapindo Persada.

Yudha, E. P., \& Hasib, F. F. (2014). Pengaruh Motivasi Terhadap Komitmen Organisasional Pada Guru Madrasah Ibtidaiyah Islamiyah Kota Madiun. 1(5), 19.

Yulita, R. (2003). Diajukan Kepada Fakultas Psikologi Universitas Islam Indonesia Untuk Menempuh Sebagian Dari Syarat-Syarat Guna Memperoleh Derajat Sarjana S-I Psikologi. 1.

\begin{tabular}{|l|l|l|l|l|}
\hline Submit & Review & Revisi & Diterima & Publis \\
\hline $06-06-20$ & - & - & $30-03-21$ & $22-04-21$ \\
\hline
\end{tabular}

Norhasanah, Mulyani, dan Shanty Komalasari

Program Studi Psikologi Islam

Fakultas Ushuluddin dan Humaniora

Universitas Islam Negeri Antasari Banjarmasin

Email: nrhsanah101@gmail.com 